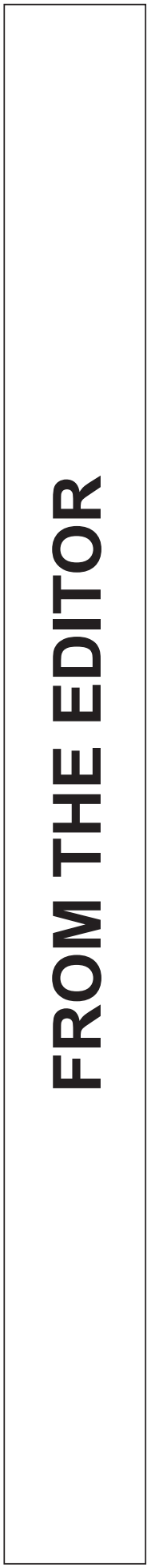



DOI : $10.14746 / p s .2021 .1 .1$

\section{HISTORY REPEATS ITSELF. THE ISSUE OF TER- RORISM AND AFGHANISTAN ON THE TWENTIETH ANNIVERSARY OF THE 9/11 ATTACKS}

The year 2021 abounded in spectacular events that have had an influence on the international situation. Two of those deserve particular attention in global terms. The first concerns the twentieth anniversary of the September 11, 2001 attacks and related questions about the evolution of terrorism, its present characteristics and the scale of the threat. The other event of the utmost importance is NATO's withdrawal from Afghanistan, followed by the Taliban rapidly taking over. This came as a surprise not only to public opinion or the political elite, but also to the vast majority of analysts who have been watching the situation there for many years. The final outcome translated into all the efforts to ensure security and stability in Afghanistan being annihilated over some twenty days or so.

The twentieth anniversary of the 9/11 attacks and the current situation in Afghanistan are closely related. They both fall within the framework of the politics of the United States on the one hand, and the ongoing war on terrorism on the other. Experts from the Watson Institute for International and Public Affairs (research center at Brown University in Providence) have estimated that, from the attacks on the World Trade Center twin towers in September 2001 to August 2021 - which is when the Taliban announced the conquest of Afghanistan, the costs of the war on terrorism exceeded $\$ 6.4$ trillion. Over 800,000 people have been killed, including ca. 335,000 civilians, and over 37 million people have been displaced, mainly in Afghanistan, Pakistan, Iraq, Syria, Libya, Yemen and Somalia. Human rights were and continue to be violated and civil liberties restricted on a regular basis in these countries. The details of human cost during the war on terrorism are presented in the table below, taking into account the number of casualties and the place of their death.

\section{TERRORISM IN THE SHADE OF THE WTC TOWERS}

Interestingly, when analyzing the first element, i.e. the issue of terrorism, it can be illustrated by means of various comparisons. In one of them, it is compared, for example, to a constantly mutating virus of a global range, which attacks in successive waves. In the times of Covid-19, this image is both current and highly suggestive. Another approach compares terrorism to an old wine served every now and then, each time in new bottles. This means that we are dealing with a timeless and global challenge that continues to evolve, to a greater or lesser extent. This evolution concerns many dif- 
Figure 1. Persons killed in the major zones of war on terrorism in 2001-2021*

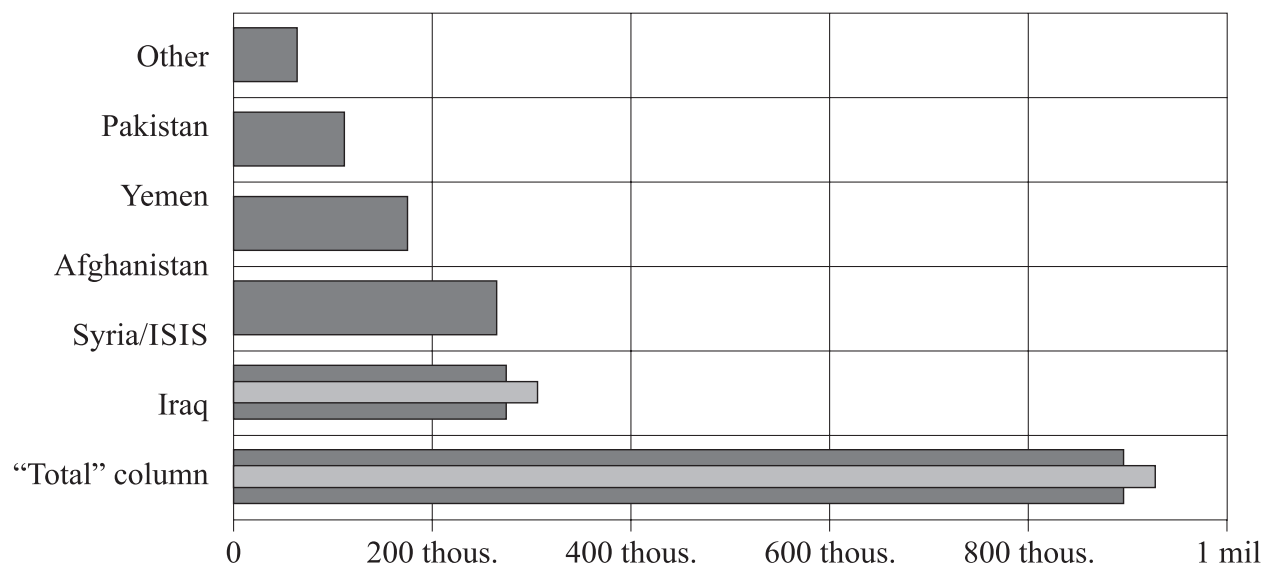

* Considerable discrepancies can be seen with respect to figures for Iraq and those in the "Total" column.

Source: Watson Institute, 20 Years of War, https:/watson.brown.edu/costsofwar/files/cow/imce/papers/2021/Costs\%20of\%20War Direct\%20War\%20Deaths 9.1.21.pdf (21.10.2021); quoted after: BIQdata, wyborcza.pl, https://biqdata.wyborcza.pl/biqdata/7,159116,27556879,20-lat-wojny-z-terroryzmem-koszty-dla-usa-polisa-ubezpieczeniowa.html?disableRedirects=true (21.10.2021).

ferent aspects, including the tactics and strategies of terrorists, ranging from ancient Assassins to modern "lone wolves" or cyberterrorists (Routledge, 2019). Yet another approach compares terrorism to an ongoing chess game, where it is not so much the players' potential that counts, as the strategy and tactics used. Individual persons often decide about victory or defeat on the "terrorist chessboard" (Wojciechowski, 2013), and their decisions often affect the future of entire nations. This was the situation we dealt with, for example, on September 11, 2001.

Terrorism takes various forms, ranging from attacks with the simplest devices, such as knives or speeding cars, through to sophisticated attacks in cyberspace and bioterrorism - a threat which is particularly real in the times of the pandemic, and is an inherent part of our reality. This is evidenced by data which shows, for example, that, statistically speaking, about 20 attacks take place somewhere in the world every day. More detailed statistics show that there were over 200,000 manifestations of terrorism worldwide in the period from 1970-2019. For example, about 80 countries on different continents were affected last year, which shows the global nature of the threat. About $80 \%$ of them were concentrated in three geographical regions, namely West Asia, South Asia and Sub-Saharan Africa. The five countries currently most threatened by terrorism include Afghanistan, Syria, India, Iraq and Somalia. The terrorist threat is generated by over 60 active groups, with the following at the helm: the Taliban, ISIS, Al-Sabah, Boko Haram and Al-Qaeda. Annually, from 11,000 to 33,000 people die and tens of thousands are wounded due to terrorism in various forms (The Global, 2021).

Covid-19 and numerous other problems in various parts of the world have caused the international community to increasingly forget about the terrorist threat. Unfortunately, however, it is still here, and in some cases it is even intensifying (Wojciechows- 
ki, 2021). The war on terrorism also continues, and it will do so. ${ }^{1}$ This is indicated by various circumstances, including increasingly frequent analyses which point to the intensifying activities of various terrorist groups, including Al-Qaeda or ISIS (Williams, 2002; McCants, 2015; Wejkszner, 2016), but also events in the Middle East, North Africa or Asia, for example in Afghanistan. ${ }^{2}$

The importance of the terrorist threat in the European Union is emphasized, for example, by the authors of the latest European Union Terrorism Situation and Trend Report 2021 by Europol. The twelfth edition of this specialist study covers 2020. Due to Brexit, the report contains mainly data taking into account the European Union in its present shape, i.e. without the United Kingdom. Nevertheless, the UK is referred to repeatedly throughout the report. ${ }^{3}$ In the European Union (including the United Kingdom), 119 successful, failed and foiled terrorist attacks were reported in 2020 (as in the previous year). Excluding the United Kingdom, there were 57 of them (compared to 55 in 2019). Last year, 24 people were killed by terrorist activity in the EU (including the UK), compared to a total of 13 deaths one year earlier. This increase is, among other things, a consequence of the bloody attack which killed 9 people in Germany in February.

In 2020, attacks (excluding the UK) were carried out by the extreme left and anarchists -25 , jihadists -14 , ethno-nationalists and separatists -14 , and by the extreme right -4 . They occurred in six countries: Italy -24 , France -15 , Spain -9 , Germany -6 , Belgium - 2, and Austria - 1. According to Europol, jihadism is still the most dangerous current of terrorism in the European Union. This is the case despite the decline in the number of attacks in this category. In 2018, 24 jihadist attacks were carried out ( 20 excluding the UK), one year later - 21 (18 excluding the UK), and in $2020-14$ excluding the UK. However, a detailed analysis shows that in 2020 (unlike in 2018 or 2019) the number of successful Islamist attacks exceeded the number of failed and foiled attacks combined. Additionally, no case of a foiled Islamist attack was recorded last year. The number of failed attacks decreased from 16 in 2018 and 14 in 2019 to 4 in 2020.

The terrorist threat is a significant outcome of the activity of jihadists in EU member states and of events outside EU territory. One example is the operations of ISIS or Al-Qaeda and related organizations that are constantly active, including in the Middle East, Africa and Asia (Country, 2019). In the coming months, the jihadist threat in the EU may intensify again, which will be related, for example, to the withdrawal of NATO forces from Afghanistan and the Taliban taking power there, the events presented by fundamentalists as spectacular examples of "the victory of Islam over the West." This is expected to encourage Islamists to continue fighting in other parts of

\footnotetext{
${ }^{1}$ For more on war on terrorism and its assessment, see e.g.: A. Lubin, Never-Ending War on Terror, University of California Press 2021; Since 9/11, the "war on terror" has been central to U.S. policy, "Foreign Affairs" 2021, vol. 100, no. 5.

${ }^{2}$ For a discussion on the situation in Afghanistan see, e.g.: A. Ahmady, Why Afghanistan Fell An Insider's Account of What Went Wrong, "Foreign Affairs", 11 October 2021, https://www.foreignaffairs.com/articles/afghanistan/2021-10-11/why-afghanistan-fell (11.10.2021).

${ }^{3}$ For more on the influence Brexit has had on terrorism in the UK see, e.g.: S. Greer, Brexit and counter terrorism in the UK, https://legalresearch.blogs.bris.ac.uk/2019/09/brexit-and-counterterrorism-in-the-uk/ (02.10.2021).
} 
Figure 2. Failed, foiled and successful jihadist attacks in the European Union 2018-2020

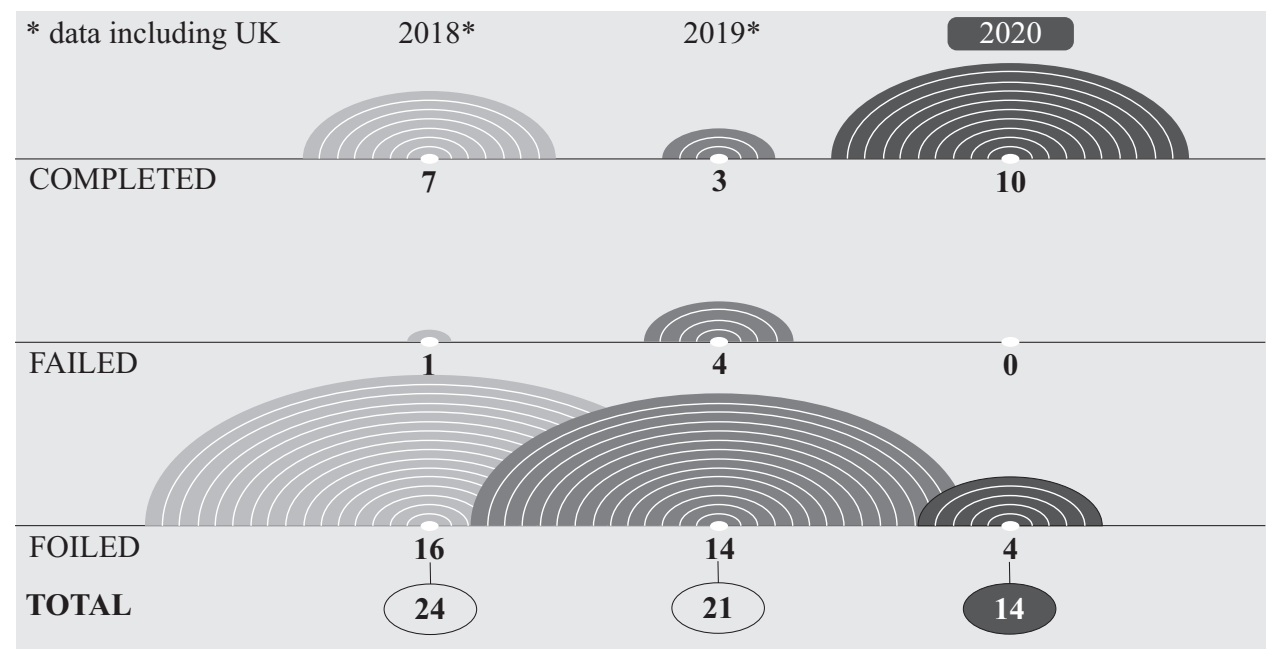

Source: European Union Terrorism Situation and Trend Report 2021, https://www.europol.europa.eu/activitiesservices/main-reports/european-union-terrorism-situation-and-trend-report-2021-tesat (11.10.2021).

the world, including the EU. The activity of Islamists will probably intensify also due to the weakening pandemic, lifting of lockdowns and other restrictions, increased movement of people, or the next wave of people who supported ISIS in various ways returning to Europe. ${ }^{4}$

Terrorism "has many names" being the sum of many different and often interrelated causes, which can be well observed on the example of the European Union (Wojciechowski, 2017). Therefore, currents of terrorism other than Islamist also deserve attention. Some of them, such as terrorism related to the extreme left-wing and anarchists, have remained at a similar level for years (19 attacks in 2018, 26 in 2019, and 25 in 2020). Indirectly, this also applies to far-right terrorism - 1 attack in 2018, 6 in 2019 (including 4 in the UK) and 4 in 2020. However, a very large change has been seen in the case of the ethno-nationalist and separatist threat. In 2018, ethno-nationalist and separatist attacks prevailed on the territory of the European Union, amounting to 83 (56 in the UK). One year later, there were 57 attacks (mainly in the UK, which accounted for 56 attacks). In 2020, however, after excluding the United Kingdom in the wake of Brexit, there were only 14 such attacks.

Another thing deserving attention concerns the correlation between migration and terrorism. The 2019 Europol Report points out that, as in previous years, there are no indications that illegal migration is systematically used by terrorist organizations. It states that, for example, citizens of a given EU country accounted for over $70 \%$ of arrests related to jihadist terrorism (European, 2021). However, according to the calculations of the British expert on terrorism, Sam Mullins, about $19 \%$ of the perpetrators of

${ }^{4}$ According to a report published by the Spanish Institute for Security and Culture (ISC), ca. 1,500 ISIS fighters returned to the EU from the Middle East by the beginning of 2018, see: https://wiadomosci.dziennik.pl/swiat/artykuly/600807, hiszpania-isis-raport-bojownicy-ue.html (09.10.2021). 
Islamist terrorist attacks carried out in the European Union from 2012 to 2020 came to Europe as asylum seekers. His analysis covers 91 attacks carried out by 123 terrorists. However, the rate was even higher in some countries, for example in Germany. Out of 13 terrorist attacks there, carried out by 14 perpetrators, half of the attackers had previously applied for asylum. German security services replied, providing other - lower numbers. This difference is due to Mullins taking into account a series of failed attacks on high-speed trains in Bavaria and Berlin, the perpetrators of which had applied for asylum in Austria and were also convicted there. ${ }^{5}$

Terrorist tactics and strategy are another important element. They usually are the sum of many directly or indirectly related components, the form of which is increasingly often hybrid (Wojciechowski, 2013) combining, among other things, the conventional and cybernetic dimensions and embracing political, social, psychological, religious, cultural, logistic, historical, financial and other aspects. In 2020, almost all attacks on the territory of the European Union were carried out by "lone wolves" (Wejkszner, 2018). In some cases, however, the perpetrators had links with other terrorist individuals or groups, and had sometimes become radicalized because of the internet or imprisonment. In some of them, extreme views alongside mental disorders were observed, as was the case, for example, of jihadists and right-wing extremists. Last year, attacks were carried out mainly with knives, speeding vehicles or involved arson. Firearms were only used during the right-wing attack in Hanau, Germany, and the jihadist attack in Vienna. Therefore, the attacks did not require advanced technology ${ }^{6}$ or financial commitment. No major act involving the use of explosives has been reported. ${ }^{7}$ This may be caused by various factors, ranging from pandemic restrictions and difficulties, the weakening logistical potential of terrorists, through to instructions issued, for example, by ISIS to carry out attacks using the simplest measures. ${ }^{8}$

Along with the Covid-19 pandemic spreading, significant changes have taken place in the tactics and strategy used by terrorists compared to the past (Legieć, 2020). On the one hand, travel restrictions, bans on public gatherings or other constraints have made terrorist activities more difficult, especially in terms of operations where a larger number of people or funds are required. On the other hand, they have forced a change in both the philosophy and logistics of operations. This concerned not only the operational sphere but, to a greater or lesser extent, also intelligence, transport, recruitment, training, propaganda, finance, and so on. This has been particularly true for groups with headquarters or operation bases located outside the European Union and less so for autonomous terrorist cells or lone wolves. Regardless of the form of activity, however, the pandemic and its consequences forced the behavior of both terrorists and

5 Junge Freiheit, https://jungefreiheit.de/politik/deutschland/2021/jeder-zweite-islamistischeattentaeter-in-deutschland-ist-fluechtling/ (05.10.2021).

${ }^{6}$ The tragic events of October 13, 2021 exemplify the use of non-advanced technology, when an Islamic convert from Denmark killed 5 people in Norway with a bow and arrows.

${ }^{7}$ By comparison, explosives were used by terrorists in around $30 \%$ of all attacks carried out in the EU in 2017, https://www.europol.europa.eu/about-europol (12.10.2021).

${ }^{8}$ ISIS published guidelines for its members and supporters on how to proceed during the Covid-19 pandemic, among others, in the online magazine "Al-Naba." They concerned, for example, rules of behavior or traveling. 
the environment supporting them (pro-terrorist environment) to keep evolving (Wojciechowski, 2013: 72 et seq.).

The 2021 Europol report stresses that terrorists use every opportunity to spread fear or propaganda. In this context, Covid-19 and the accompanying increase in internet use have turned out to be a very favorable circumstance for them. On the one hand, the internet has been used to promote hatred, and on the other, to integrate supporters. Since using the Telegram messenger became more difficult (end of 2019), Islamists have had problems finding a universal communication channel, which is why their propaganda is spread across various platforms. However, it still remains effective and dangerous. The activity of other extremist groups, mainly extreme right- or left-wing ones, on the internet is also intensifying. In addition to traditional topics, these groups eagerly address new ones such as, for example, environmental, technological or pandemic issues. Both Islamists and right-wing extremists have tried to use Covid-19 for propaganda purposes. By contrast, left-wing and anarchist extremists have mainly criticized measures taken by governments to combat the pandemic.

When analyzing the forms and methods of terrorist activity in the European Union from 2018-2020, it is worth mentioning three terrorist activities where the use of weapons of mass destruction was planned in 2018. During the same period, Europol also noted an increase in terrorist propaganda referring to the use of measures of mass destruction (for example, by posting training or instructional materials) (European, 2020). In 2019, the head of the Europol anti-terrorist center, Manuela Navarrete, stressed the fact that the threat from people leaving prison who had been convicted of terrorist offenses or those who were radicalized while serving their sentence was growing in many European Union member states. ${ }^{9}$

Another important factor concerns terrorist suspects being arrested. In the European Union (excluding the UK), the number of people arrested for terrorist activities significantly decreased, from 783 cases in 2018 and 723 in 2019 to 449 in 2020. According to the authors of the latest Europol report, it is difficult to say clearly whether this indicates reduced activity of terrorists or results from limited capacity of security services during the pandemic. In 2018, out of a total number of 1,056 detainees, the largest numbers were recorded in France - 310, the United Kingdom - 273, Belgium - 166, Germany -59 , Italy -56 , Spain -52 , and the Netherlands -49 . The majority of arrests concerned jihadists - 511 (mainly in France - 273, the Netherlands - 45, Germany - 43, and Italy -40 ). These were followed by arrests of supporters of the extreme right - 44 (mainly in France - 32), extreme left and anarchists - 34 (mainly in Greece - 30), ethno-nationalists and separatists - 30 (mainly in Spain - 20). One year later, there were 1,004 arrests, including 281 in Great Britain, 224 in France, 132 in Italy, 99 in Belgium, and 91 in Spain. Persons suspected of Islamist activity clearly dominated -436 , followed by the supporters of the extreme left and anarchists - 111, ethno-nationalists and separatists -48 , and the far-right -21 (European, 2019, 2020, 2021).

For a change, in 2020, most cases (around 57\%) concerned jihadist terrorism - 254, extreme left-wing and anarchist - 52, ethno-nationalist and separatist - 39 and extreme right-wing terrorism - 34. Most people were arrested in France - 127, Belgium - 61,

${ }_{9}$ Terrorism in the EU: Terror attacks, deaths and arrests in 2019, https://moderndiplomacy. eu/2020/07/16/terrorism-in-the-eu-terror-attacks-deaths-and-arrests-in-2019/ (11.10.2021). 
Spain -57 , Italy - 45, and Germany - 44. It should be emphasized that the detainees were getting increasingly younger and they were often minors.

Figure 3. People arrested for terrorism by EU member state 2020

\begin{tabular}{|c|c|c|c|c|c|c|c|}
\hline $\begin{array}{l}\text { Member } \\
\text { State }\end{array}$ & $\begin{array}{l}\text { Jihadist } \\
\text { terrorism }\end{array}$ & $\begin{array}{l}\text { Right-wing } \\
\text { terrorism }\end{array}$ & $\begin{array}{c}\text { Left-wing } \\
\text { and anarchist } \\
\text { terrorism }\end{array}$ & $\begin{array}{l}\text { Ethno-nationalist } \\
\text { and separatist } \\
\text { terrorism }\end{array}$ & $\begin{array}{l}\text { Other types } \\
\text { terrorism }\end{array}$ & $\begin{array}{c}\text { Not } \\
\text { specified }\end{array}$ & TOTAL \\
\hline Austria & 30 & & & & & & 30 \\
\hline Belgium & 2 & 1 & & & & 58 & 61 \\
\hline Bulgaria & 1 & & & & & & 1 \\
\hline Czechia & & & & & 1 & & 1 \\
\hline Cyprus & 1 & & & & & & 1 \\
\hline Denmark & 1 & & & 3 & & & 4 \\
\hline France & 99 & 5 & 11 & 12 & - & - & 127 \\
\hline Germany & 27 & 14 & & 3 & & & 44 \\
\hline Grece & 3 & & 14 & & & & 17 \\
\hline Ireland & 18 & & & 6 & & & 24 \\
\hline Italy & 10 & 1 & 24 & 1 & & 9 & 45 \\
\hline Luxemborg & & 1 & & & & & 1 \\
\hline Netherlands & 15 & 6 & & 2 & & 1 & 24 \\
\hline Poland & 8 & 1 & & & & & 9 \\
\hline Portugal & & & 1 & & & & 1 \\
\hline Romania & 2 & & & & & & 2 \\
\hline Spain & 37 & 5 & 2 & 12 & & 1 & 57 \\
\hline TOTAL & 254 & 34 & 52 & 39 & 1 & 69 & 449 \\
\hline
\end{tabular}

Source: European Union Terrorism Situation and Trend Report 2021, https://www.europol.europa.eu/activitiesservices/main-reports/european-union-terrorism-situation-and-trend-report-2021-tesat (07.10.2021).

The attacks on the United States, the twentieth anniversary of which fell on September 11,2021, testify to the determination of the perpetrators and to the great trauma of the victims and their families. Even though 20 years have passed since the 9/11 events, many Americans remain highly emotional about them. This is also illustrated by various manifestations of memory, stereotypes and prejudices, disputes and unexplained issues. Numerous lawsuits and compensation payments are still being continued, procedures and security systems are being improved, and the accompanying restrictions apply. The infamous Guantanamo prison is still operating, despite repeated announcements of its liquidation.

\section{AFGHANISTAN - THE VICTORY OF "A BUNCH OF SHEPHERDS", SO WHAT NEXT?}

The second element mentioned above concerns the situation in Afghanistan, both internally and internationally. Afghans as a community are extremely proud of their 
history, but they are also people who have repeatedly suffered a brutal fate. The next episode of their trauma began in 2021, in association with the withdrawal of NATO forces from the country and the Taliban rapidly returning to power.

In Pashto, the word Talib apparently evokes positive connotations as it means a student - a person seeking knowledge. Indeed, initially, these formations originated among students of Islamic Koranic schools. However, they quickly acquired a military character, becoming a political force seeking to seize power and create a radical religious state. Thanks to their spectacular successes and skillful strategy, from 1996 to 2001 they controlled the situation in most of Afghanistan by introducing a brutal Sharia-based regime. This is an orthodox Islamic legal and political system that rejects all Western values and introduces and enforces a number of brutal prohibitions or orders. The first Taliban government also violated basic civil rights. This was experienced, in particular, by opposition activists and representatives of ethnic or religious minorities, among others (Jones, 2010).

The Taliban's support for Islamic terrorist organizations created another threat. This mainly concerned al-Qaeda and its leadership, with Osama bin Laden at the helm. His terrorists involved in the bloody attacks carried out in the United States on September 11, 2001 had been welcome by the Taliban. Not only were the twin towers of the World Trade Center destroyed in these attacks, but 2,973 people were killed, excluding the 19 hijackers and 26 victims still officially missing. In the wake of these events, President George Bush made the decision to send armed forces to Afghanistan and proclaimed the war on terrorism, which in many parts of the world continues until this day. In the case of Afghanistan alone, the war cost \$2.2 trillion, well above US spending during World War II. The main goal of the Afghan mission carried out first by the United States, and later by NATO and their allies, initially as part of the International Security Assistance Force (2001-2014) (ISAF's, 2021), and later as part of the Resolute Support Mission in Afghanistan (2015-2021) (Resolute, 2021) was not only to defeat terrorists or Islamic fundamentalists, but also to bring security and stability to this country, including by financing, training and equipping Afghan security forces.

Despite the involvement of enormous financial resources in Afghanistan, and the presence of over 100,000 troops, NATO failed to achieve its planned goals. As time passed, the Taliban began to regain the initiative. In order not to further increase financial outlays and human losses (over 2,200 casualties), and hoping that the Afghan authorities could maintain control over at least part of the territory with the support of government security forces, the US administration decided to strategically retreat. This was, in fact, an admission of defeat - the war was definitely lost. Despite the commitment and dedication of thousands of soldiers and civilians, not only the United States, but all the states united under the NATO banner were defeated. Ironically, the victory belonged to "a bunch of shepherds," as one of the American generals scornfully put it. How is it possible that they defeated the strongest alliance in the world? Contrary to a popular saying, this failure had many "fathers," and was caused by NATO overestimating its own strength and capacity, while underestimating "a bunch of illiterate shepherds." It was they who, thanks to the proper strategy, their determination, fanaticism even, their familiarity with the area and its topography, profits from drugs, external help, the support or intimidation of parts of society, as well as turning 
NATO's mistakes to their advantage, showed once again how a symbolic David can defeat Goliath. In this situation, the United States began negotiations with the Taliban. This resulted in an agreement concluded by President Donald Trump. According to its provisions, US forces were to leave Afghanistan by May 1, 2021. Due to the Taliban having failed to fulfil some of their obligations, among other things, this deadline was initially questioned by the new president, Joe Biden, who proposed to reduce the military presence later and more gradually. Unexpectedly, however, on April 12, despite numerous critical voices also from some of his associates, President Biden suddenly changed his mind and announced that by September 11, the twentieth anniversary of the 2001 attacks, US troops would leave Afghanistan. Following the US decision, other NATO member states also decided to withdraw their troops "recognizing that there is no military solution to the challenges Afghanistan faces." This also applied to Poland, which had been militarily involved there since 2002. In total, there were over 33,000 Polish soldiers and civilians on Afghan territory. Sadly, over 40 soldiers were killed and around 400 sustained injuries.

The pace and momentum of the Taliban offensive following the withdrawal took both experts and politicians by surprise. This was best evidenced by the panic that swept first across the residents of Afghan cities, and then foreigners staying, among other places, in Kabul. Speaking in simple terms, 20 years of efforts by the international community to build a relatively stable and safe Afghanistan were wiped out in 20 days. How was this possible? What happened to the over 300,000 strong Afghan security forces, which the United States alone spent over $\$ 88$ billion on training? These formations were supposed to guarantee that control would be maintained over at least part of the territory, even after the withdrawal of NATO troops. This case is likely to undergo extensive examination in various training and analytical centers around the world for a very long time. Yet the first conclusions can already be made. They point to, for example, a long list of errors in the structure or logistics of Afghan armed formations, the low effectiveness of training courses and even lower morale of both soldiers and officers. All this is additionally complemented by significant support for Islamists among the soldiers, and omnipresent corruption, resulting in entire large military units, as well as city or provincial authorities taking the Taliban side. There were also frequent cases where data on the numbers, training or equipment of the army or police were invented in order to obtain additional funds. Above all, many Afghan men in uniforms had neither the will nor the motivation to fight, or even die in the name of ... - in the name of what, precisely? Of the president, government, Western interests, money, democracy, or human rights? For some Afghans, these are "empty words" not worth risking their life or the lives of their families for.

Islamic terrorism is yet another very important problem in the case of Afghanistan. Not only is the level of terrorist threat in this country the highest in the world, but it is also a refuge for members of various Islamist armed organizations operating in many parts of the world. This threat intensified even more when the Taliban released all extremists from prisons. This is accompanied by new challenges, such as the escalation of Islamic fundamentalism into other countries, the spread of the migration crisis, the Covid-19 pandemic, the outbreak of another armed conflict in Afghanistan and the disruption of the balance of power in this region, which is very unstable and involves 
players such as China, India, Pakistan Iran and Russia. In order to solve at least some of the above problems, a dialogue is necessary first of all, as well as the concerted commitment of the international community, and in particular of the great powers, including the United States, Russia and China, something that is always difficult.

Other motives for interest in Afghanistan should not be ignored, including huge deposits of iron, copper, gold, cobalt, coal, rare earth metals, and above all lithium, which is necessary in electronics, medicine or space technologies. Very conservative estimates point to their total value of at least $\$ 1$ trillion. In this context, the words quoted by $\mathrm{CNN}$, and taken from a report by American geological services, sound significant: "If Afghanistan has a few years of calm, allowing the development of its mineral resources, it could become one of the richest countries in the area within a decade." Rod Schoonover, a security expert and founder of the Ecological Futures Group, speaks in the same vein: "Afghanistan is certainly one of the regions richest in traditional precious metals, but also the metals [needed] for the emerging economy of the 21st century" (Factbox, 2021; The War, 2021).

Figure 4. Location, size and worth of the main natural resources in Afghanistan

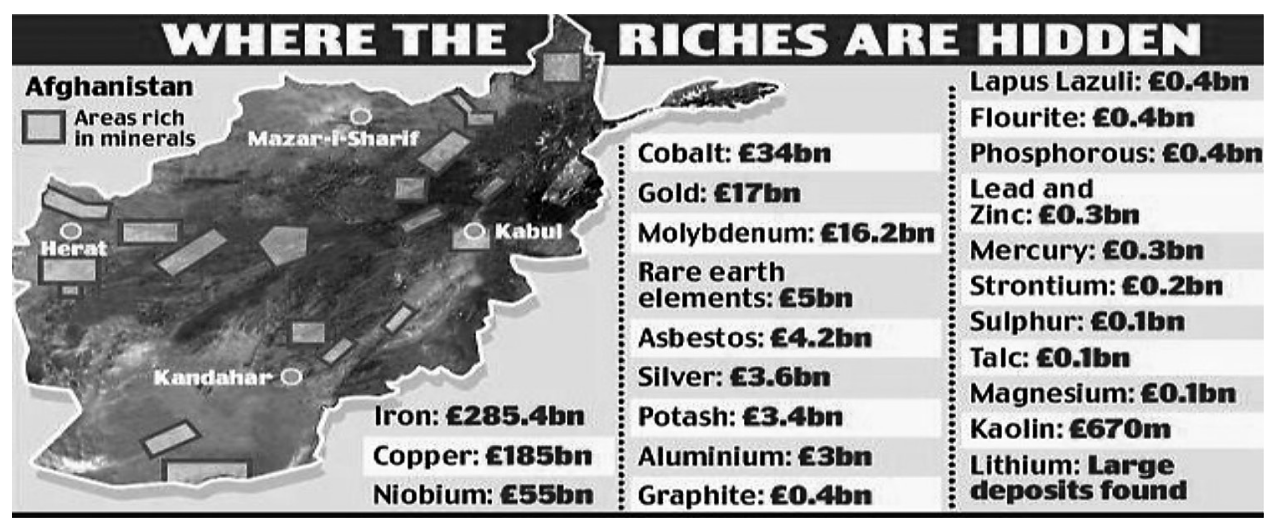

Source: Ground Report, https://www.groundreport.com/afghanistan-holds-trillions-of-dollars-of-natural-resources-including-mineral-wealth-and-hydrocarbons-said-karzai/ (06.11.2021).

Another key factor involves the possibility of establishing bases or installations, for example, for military or intelligence purposes, on the territory of Afghanistan. This is particularly important due to the country's location in a sensitive region, attracting the attentions of China, Iran, India, Pakistan and Russia, among others. Afghanistan is therefore important not only in political, economic and military, but also geopolitical terms. Other issues also deserve attention, including the very difficult economic and social situation which exists, despite the above-mentioned mineral resources and the development aid provided by the international community. Its purpose was for Afghanistan to overcome its backwardness and recover from war damage, including the aftermath of the military intervention of the USSR (1979-1989). The scale of Afghan poverty is indicated by a range of different indexes, such as illiteracy exceeding $60 \%$ (in the case of women, probably even $80 \%$ ), the world's highest infant mortality rate, or the fact that $90 \%$ of the country's population live on less than $\$ 2$ daily. In one of its 
reports, the World Bank described the Afghan economy emphatically as "shaped by fragility and aid dependence."

Afghanistan's destabilization has been, and will likely continue to be, caused by the production and trafficking of drugs, which, on account of corruption or porous state borders, are supplied in thousands of tons to various parts of the world, including the United States and Europe. According to the United Nations, Afghanistan is the world's largest producer of opium, accounting for over $80 \%$ of its global production. Also, $95 \%$ of the world's opium-based heroin is produced in Afghanistan. The proceeds are estimated at around $\$ 3$ billion a year. The UN estimates that illegal poppy cultivation and the production and sale of opiates account for 7-11\% of Afghanistan's GDP. The cultivation of poppies gives about 120,000 jobs and is the largest sector of the Afghan economy in terms of employment.

Figure 5. Opium poppy cultivation in Afghanistan, 1994-2020 (hectares)

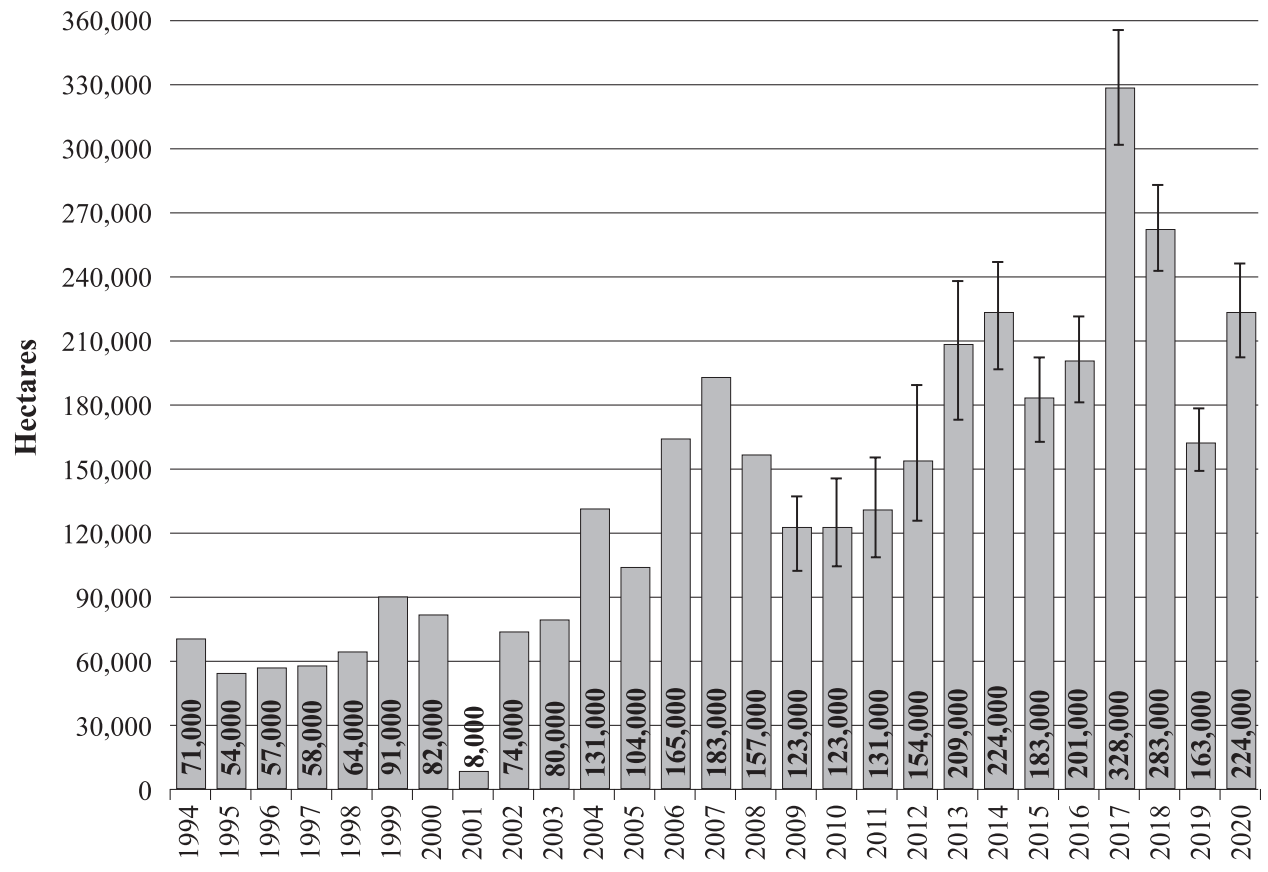

Source: MCN/UNODC opium surveys 1994-2018; NSIA/UNODC opium surveys 2019 onwards. The vertical lines represent the upper and lower bounds of the 95\% confidence interval, see: UNODC Afghanistan Opium Survey 2020 Cultivation and Production - Executive Summar, April 2021, Microsoft Word - 20210628_AOS 2020 cult prod working.docx (unodc.org) (11.11.2021).

According to the US Special Inspector General for Afghanistan Reconstruction (SIGAR), illegal poppy cultivation and drug production account for nearly $60 \%$ of the Taliban's annual income. The UN estimates that the Taliban earn \$100-400 million each year, consistently increasing production and profits. Over the past 15 years, the United States has spent more than $\$ 8$ billion fighting the drug industry in Afghanistan, but to no avail. 
What does the future hold for Afghanistan? Will the Taliban really live up to their promises to respect women's rights, transfer power to civilians, and so on - or will they return to exercising brutal power after a transition period? Will they try to solve the many problems that plague the country, such as famine that threatens 14 million citizens? Or maybe another civil war will break out with local forces which refuse to accept the new government? What action will the international community, and the great powers in particular, take against the Taliban? Will Afghanistan become another zone of Chinese influence? What policy will the United States, Russia, India and Pakistan pursue towards the Taliban? We do not know the answers to these questions at the moment. However, the tragedy in Afghanistan is taking place against a background of other issues related to regional or even global security. In many cases, for example in relation to the problem of terrorism or the situation in Afghanistan, they show that history repeats itself.

We are presenting another issue, this time the fourteenth, of "Strategic Review", hoping for its friendly reception on the one hand and numerous comments and remarks on the other. We have divided the journal into four sections this year. The first one, SECURITY ASPECTS OF EU COUNTRIES focuses on selected aspects of external operations of the European Union and EU member states, including various challenges and threats. This section features the following articles: (1) International Order and the Access Problem of the Defeated Hegemon: the Case of Russia in the Post-Cold War Era; (2) The EU Global Strategy - 5 Years After; (3) The European Union-Japan Strategic Partnership in the Contested Global Order. External Relations of the EU in the Context of Economic, Normative and Security Framework; (4) Debt Security of CEE Countries: Actual Approaches and Methods of Evaluation; (5) Anne Applebaum's Strategy of Telling the History of International Relations in Central and Eastern Europe; (6) The Weimar Triangle: France, Germany, Poland in the Middle East. United Arab Emirates'Perspective; (7) Borders, De-borderization and Migration Narratives in Hungary.

The second section addresses selected security aspects of the Russian Federation, such as Russian strategic culture, Russia's security in the context of Central Asia, the problem of Islam or Russian-Ukrainian confrontation. This section is entitled SECURITY ASPECTS OF THE RUSSIAN FEDERATION and features the following articles: (1) Russian Strategic Culture: Why The Past Matters; (2) Soviet Legacy Threatens Russia's Security: Central Asian Case; (3) Seeking a Place for Islam in Post-soviet Russia; (4) Use of "The Other/Alien" Image in The Strategic Communications of The Russian Federation during The Russian-Ukrainian Confrontation (2004-2021); (5) Cursory Viewpoint on Transnistria as the Focus of the Russian Federation Policy; (6) Passion for Putin's Palace: Political Protests in Modern Russia; (7) The Dilemma of War and Peace in the Trend of the XXI Century (Russian - Ukrainian Case).

This corresponds with the third section, TERRITORIAL ASPECTS OF SECURITY, which discusses, among other things, the issues of the status of Donbas, the cases of Nigeria, Iran, China or Central Asia. It features the following articles: 
(1) Illegal Control Over the Territory in International Law and the Status of Donbas Determination; (2) Edward Azar's Protracted Social Conflict Theory and Drivers of Self-Determination: The Case of Nigeria; (3) Prospects for China's BRI and Strategic Influence in the Post-Covid-19 Central Asia; (4) Understanding the Reasons for Transition from the Iranian Constitutional State to an Authoritarian State: an Analysis in the Framework of Laclau and Mouffe's Discourse Theory; (5) Cities Towards Global Climate Governance: How the Practices of City Diplomacy Foster Hybrid Multilateralism; (6) The Concept of China's Peaceful Rise and Offensive Realism.

The fourth section is entitled HUMAN ASPECTS OF SECURITY. It includes texts which present various aspects of this topic, such as: (1) Biopolitical Reflection of Human Safety: Ukrainian and Belarusian Experience; (2) Institutional and Legal Mechanisms for Protection of the Rights of the Ukrainian Minority in the Warmia and Mazury Region; (3) Identification as an Indicator of Social Entropy Under Globalization: Ukrainian Realities and the International Context; (4) The Subjectness of Digital Communication in the Context of the Technological Evolution of Contemporary Society: Features, Threats, and Transformation Scenarios; (5) Determinants of the Participation of the People's Republic of China in the United Nations Mission in South Sudan; (6) Cultural Security of Ukraine; (7) State Policy towards Demographic Change in Poland.

It would have been impossible to prepare this issue without the involvement and support of many people. Therefore, I would like to take this opportunity to express my sincere thanks to the editorial board, reviewers, translators, technical editor and publisher, the program board as well as the Rector and Deans, by referring to the old Latin maxim Alter alterum docet.

\section{Sebastian WOJCIECHOWSKI \\ Editor in Chief}

\section{REFERENCES}

1,500 ISIS fighters returned to the EU from the Middle East by the beginning of 2018, see: https:// wiadomosci.dziennik.pl/swiat/artykuly/600807, hiszpania-isis-raport-bojownicy-ue.html.

Ahmady A. (2021), Why Afghanistan Fell An Insider's Account of What Went Wrong, "Foreign Affairs", 11 October, https://www.foreignaffairs.com/articles/afghanistan/2021-10-11/whyafghanistan-fell.

Country Reports on Terrorism 2019, https://www.state.gov/reports/country-reports-on-terrorism-2019/.

European Union Terrorism Situation and Trend Report 2019, https://www.europol.europa.eu/activities-services/main-reports/european-union-terrorism-situation-and-trend-report-2019-tesat.

European Union Terrorism Situation and Trend Report 2020, https://www.europol.europa.eu/activities-services/main-reports/european-union-terrorism-situation-and-trend-report-2020-tesat.

European Union Terrorism Situation and Trend Report 2021, https://www.europol.europa.eu/activities-services/main-reports/european-union-terrorism-situation-and-trend-report-2021-tesat.

Factbox: What are Afghanistan's untapped minerals and resources?, https://www.reuters.com/world/ asia-pacific/what-are-afghanistans-untapped-minerals-resources-2021-08-19/. 
Greer S., Brexit and counter terrorism in the UK, https://legalresearch.blogs.bris.ac.uk/2019/09/ brexit-and-counter-terrorism-in-the-uk/.

ISAF's mission in Afghanistan (2001-2014) (Archived), https://www.nato.int/cps/en/natohq/topics 69366.htm.

Jones S. (2010), In the Graveyard of Empires. America's War in Afghanistan, New York.

Junge Freiheit, https://jungefreiheit.de/politik/deutschland/2021/jeder-zweite-islamistische-attentaeter-in-deutschland-ist-fluechtling/.

Legieć A. (2020), Wpływ pandemii COVID-19 na zagrożenie terrorystyczne w UE, PISM, https:// www.pism.pl/publikacje/Wplyw_pandemii_COVID19_na_zagrozenie_terrorystyczne_w_ UE.

Lubin A. (2021), Never-Ending War on Terror, University of California Press 2021; Since 9/11, the "war on terror" has been central to U.S. policy, "Foreign Affairs", vol. 100, no. 5.

McCants W. (2015), The ISIS Apocalypse: The History, Strategy, and Doomsday Vision of the Islamic State, St. Martin's Press.

Resolute Support Mission in Afghanistan (2015-2021), https://www.nato.int/cps/en/natohq/topics_113694.htm.

Routledge Handbook of Terrorism and Counterterrorism (2019), (ed.) A. Sillke, London-New York.

Terrorism in the EU: Terror attacks, deaths and arrests in 2019, https://moderndiplomacy. $\mathrm{eu} / 2020 / 07 / 16 /$ terrorism-in-the-eu-terror-attacks-deaths-and-arrests-in-2019/.

The Global Terrorism Database (GTD), The National Consortium for the Study of Terrorism and Responses to Terrorism (START), https://start.umd.edu/gtd/about/.

The War is Worth Waging: Afghanistan's Vast Reserves of Minerals and Natural Gas, https://www. globalresearch.ca/the-war-is-worth-waging-afghanistan-s-vast-reserves-of-minerals-andnatural-gas/19769.

UNODC Afghanistan Opium Survey 2020 Cultivation and Production - Executive Summar, April 2021, Microsoft Word - 20210628_AOS 2020 cult prod working.docx (unodc.org).

Watson Institute, 20 Years of War, https://watson.brown.edu/costsofwar/files/cow/imce/papers/2021/ Costs\%20of\%20War_Direct\%20War\%20Deaths_9.1.21.pdf.

Wejkszner A. (2016), Państwo Islamskie. Narodziny nowego kalifatu?, Warszawa.

Wejkszner A. (2017), Globalna sieć Al-Kaidy, Nowe państwo islamskie?, Warszawa.

Wejkszner A. (2018), Samotne wilki kalifatu? Państwo Islamskie i indywidualny terroryzm dżihadystyczny w Europie Zachodniej, Warszawa.

Williams P. (2002), Al Qaeda: Brotherhood of Terror, Alpha.

Wojciechowski S. (2013), The Hybridity of Terrorism. Understanding Contemporary Terrorism, Berlin.

Wojciechowski S. (2017), Reasons of Contemporary Terrorism. An Analysis of Main Determinants, in: Radicalism and Terrorism in the $21^{\text {st }}$ Century, (eds.) A. Sroka, F. Castro-Rial Garrone, R. Torres Kumbrian, Frankfurt am Main.

Wojciechowski S., Osiewicz P. (2017), Zrozumieć wspótczesny terroryzm. Wybrane aspekty fenome$n u$, Warszawa. 